\title{
TDGF1 Gene
}

National Cancer Institute

\section{Source}

National Cancer Institute. TDGF1 Gene. NCI Thesaurus. Code C153275.

This gene plays a role in the modulation of signaling by the growth factor Nodal homolog. 